\title{
Genetics of chronic nonbacterial osteomyelitis in the irish population: no significant association with rare FBLIM1 variants
}

\author{
Daire O'Leary ${ }^{1,2^{*}}$, Orla G Killeen ${ }^{1}$ and Anthony G Wilson ${ }^{2}$
}

Keywords: Chronic nonbacterial osteomyelitis, CNO, Chronic recurrent multifocal osteomyelitis, CRMO,

Autoinflammation, FBLIM1 gene

\section{Dear Sir,}

We read with interest the recent article by d'Adamo et al. demonstrating a high prevalence of rare FBLIM1 gene variants in an Italian cohort with $\mathrm{CNO}$ [1]. This showed $22 \%$ of 80 patients with CNO carried at least one rare variant in FBLIM1 with a gnomAD global minor allele frequency (MAF) less than 0.02. The FBLIM1 gene was first implicated in the pathogenesis of CNO by Cox et al. who identified rare variants in 2 patients of South East Asian descent, one of whom had consanguineous parents resulting in a recessively inherited form of the disease [2]. In addition, there was statistically significant enrichment of a nonsynonymous missense variant rs114077715 (p.Gly311Arg) in a European-American population with $\mathrm{CNO}$ [2]. These findings in the context of Fblim1 expression of in the cmo murine model suggested a role either for these FBLIM1 variants or a variant in close linkage disequilibrium to them in the pathogenesis of CNO. In the Italian cohort, the MAF of rs114077715 was 0.013 , which was not significantly enriched compared to the gnomAD global MAF of 0.019 (odds ratio 0.64, $p=$ 0.77). The MAF of the synonymous variant rs 140170023 was 0.063 , which was statistically significantly enriched

\footnotetext{
*Correspondence: daire.oleary@ucdconnect.ie

'National Centre for Paediatric Rheumatology, Children's Health Ireland, Dublin, Ireland

${ }^{2}$ UCD Centre for Arthritis Research, School of Medicine, University College Dublin, Dublin, Ireland
}

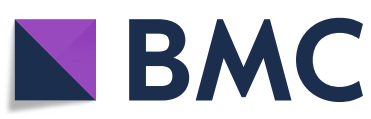

(C) The Author(s). 2021 Open Access This article is licensed under a Creative Commons Attribution 4.0 International License, which permits use, sharing, adaptation, distribution and reproduction in any medium or format, as long as you give appropriate credit to the original author(s) and the source, provide a link to the Creative Commons licence, and indicate if changes were made. The images or other third party material in this article are included in the article's Creative Commons licence, unless indicated otherwise in a credit line to the material. If material is not included in the article's Creative Commons licence and your intended use is not permitted by statutory regulation or exceeds the permitted use, you will need to obtain permission directly from the copyright holder. To view a copy of this licence, visit http://creativecommons.org/licenses/by/4.0/ The Creative Commons Public Domain Dedication waiver (http://creativecommons.org/publicdomain/zero/1.0/) applies to the data made available in this article, unless otherwise stated in a credit line to the data. compared to the gnomAD global allele count of $2993 / 253$, 068 or MAF of 0.012 (odds ratio $5.64, p=2.2 \times 10^{-5}$ ).

Sporadic forms of chronic nonbacterial osteomyelitis (CNO) demonstrate significant clinical heterogeneity between cohorts; from unifocal, non-recurrent disease to recurrent multifocal disease and disease associated with extraosseous inflammatory manifestations similar to synovitis acne hyperostosis osteitis (SAPHO) syndrome [3]. This clinical heterogeneity may reflect a similar genetic heterogeneity. Assmann et al. demonstrated that FBLIM1 variants do not appear to play a significant role in the pathogenesis of SAPHO syndrome in a European population which also included a small number of patients with $\mathrm{CNO}$ [4]; disease heterogeneity may explain the lack of association in this cohort .

In order to ascertain the frequency of variants in FBLIM1 in an Irish cohort of patients with CNO compared to the gnomAD non-Finnish European (gnomAD NFE) population, we have recruited 43 Irish children and adolescents with $\mathrm{CNO}$ currently attending paediatric rheumatology services. Ethical approval for this study was obtained from Children's Health Ireland $(\mathrm{CHI})$ at Crumlin (GEN/572/17) and CHI at Temple St (17.075). All participants met the Bristol criteria for diagnosis of CNO [5] and all were ethnically Irish. Whole exome sequencing was performed using Agilent SureSelect XT Human All Exon V6 kits and Illumina HiSeq 3000 with $150 \mathrm{bp}$ paired-end reads. Reads were aligned to the hg19 
reference genome using BWA software [6], duplicates removed using Picard tools and GATK software [7] used to realign indels and call variants. The resulting VCF files were annotated using wAnnovar. Rarer variants with a gnomAD NFE minor allele frequency (MAF) $</=$ 0.05 , were hard filtered for mapping quality $(\mathrm{MQ}>40)$ and depth of coverage $(\mathrm{QD}>2)$. A MAF of $<0.05$ was selected in order to include previously published candidate variants. Statistical analysis was performed in RStudio (version 1.1.456) using Fisher exact test.

Only $5 / 43 \quad(11.62 \%)$ individuals had variants in FBLIM1 with MAF $<0.02$ each of whom carried a single variant in a heterozygous state. Four carried the missense variant rs114077715 (p.Gly311Arg) indicating a MAF in this population of 0.0465 with no significant enrichment (gnomAD NFE MAF $=0.0264$, OR $1.79, p=0.29$ ). One carried the synonymous minor allele rs140170023 indicating a similar MAF to that reported in gnomAD (NFE $\mathrm{MAF}=0.017$ ). No variants were present with a MAF between 0.03 and 0.05 .

In conclusion, variants in FBLIM1 do not occur at a significantly higher prevalence than expected in the Irish paediatric population with $\mathrm{CNO}$ compared to gnomAD non-Finnish European allele frequencies. This does not exclude a role for FBLIM1 variants in the pathogenesis of $\mathrm{CNO}$ in certain populations but may suggest genetic differences related to ethnicity or clinical phenotype.

\section{Abbreviations}

CNO: Chronic nonbacterial osteomyelitis; SAPHO: Synovitis acne hyperostosis osteitis; MAF: Minor allele frequency; NFE: Non-Finnish European;

MQ: Mapping quality; QD: Depth of coverage

\section{Acknowledgements}

The authors wish to acknowledge the participants and their parents for agreeing to participate in this study.

\section{Authors' contributions}

DOL, OK and AGW designed the study. DOL collected the data, performed the analysis, drafted the initial manuscript, confirmed revisions, and approved the final manuscript as submitted. All authors approved the final manuscript as submitted and agree to be accountable for all aspects of the work.

\section{Funding}

Funding was received from the National Children's Research Centre (grant number G/17/1) and the UCD Foundation AbbVie SOBI Nordic Pharma Newman Fellowship in Rheumatology.

Availability of data and materials

The data and materials from this study can be made available on request.

\section{Declarations}

Ethics approval and consent to participate

Ethical approval for this study was obtained from Children's Health Ireland (CHI) Research and Ethics committees at Crumlin (REC GEN/572/17) and Temple Street (Reference 17.075).

\section{Consent for publication}

Written consent was obtained from all parents/guardians and participants age $>18$ years of age. Written assent was obtained from all participants age $<18$ years.

\section{Competing interests}

The authors declare that they have no competing interests.

Received: 23 September 2020 Accepted: 10 March 2021

Published online: 17 March 2021

\section{References}

1. d'Adamo AP, Bianco AM, Ferrara G, La Bianca M, Insalaco A, Tommasini A, et al. High prevalence of rare FBLIM1 gene variants in an Italian cohort of patients with Chronic Non-bacterial Osteomyelitis (CNO). Pediatr Rheumatol Online J. 2020 Jul 10;18(1):55.

2. Cox AJ, Darbro BW, Laxer RM, Velez G, Bing X, Finer AL, et al. Recessive coding and regulatory mutations in FBLIM1 underlie the pathogenesis of chronic recurrent multifocal osteomyelitis (CRMO). PLoS One. 2017;12(3): e0169687.

3. Girschick H, Finetti M, Orlando F, Schalm S, Insalaco A, Ganser G, et al. The multifaceted presentation of chronic recurrent multifocal osteomyelitis: A series of 486 cases from the Eurofever international registry. Rheumatol (United Kingdom). 2018;57(7).

4. Assmann G, Köhm M, Schuster V, Behrens F, Mössner R, Magnolo N, et al. Genetic variants in FBLIM1 gene do not contribute to SAPHO syndrome and chronic recurrent multifocal osteomyelitis in typical patient groups. BMC Med Genet. 2020 Dec 12;21(1):102.

5. Roderick MR, Ramanan AV. Chronic recurrent multifocal osteomyelitis. Adv Exp Med Biol. 2013;764:99-107.

6. Li H, Durbin R. Fast and accurate long-read alignment with BurrowsWheeler transform. Bioinformatics. 2010 Mar 1;26(5):589-95.

7. McKenna A, Hanna M, Banks E, Sivachenko A, Cibulskis K, Kernytsky A, et al. The Genome Analysis Toolkit: a MapReduce framework for analyzing nextgeneration DNA sequencing data. Genome Res. 2010 Sep 1;20(9):1297-303.

\section{Publisher's Note}

Springer Nature remains neutral with regard to jurisdictional claims in published maps and institutional affiliations.

Ready to submit your research? Choose BMC and benefit from:

- fast, convenient online submission

- thorough peer review by experienced researchers in your field

- rapid publication on acceptance

- support for research data, including large and complex data types

- gold Open Access which fosters wider collaboration and increased citations

- maximum visibility for your research: over $100 \mathrm{M}$ website views per year

At $\mathrm{BMC}$, research is always in progress.

Learn more biomedcentral.com/submissions 